\title{
EMPIRICAL STUDY ON THE IMPACT OF EVALUATION OF INTANGIBLE ASSETS ON THE MARKET VALUE OF THE LISTED COMPANIES
}

\author{
Cristina Gabriela Cosmulese ${ }^{1}$, Marian Socoliuc ${ }^{2}$, \\ Marius-Sorin Ciubotariu ${ }^{3}$, Veronica Grosu ${ }^{4}$, Dorel Mateş ${ }^{5}$
}

\footnotetext{
1 "Stefan cel Mare" University, Faculty of Economics and Public Administration, Department of Accounting, Audit and Finance, Romania, ORCID: 0000-0002-8406-7004, gabriela.cosmulese@usm.ro;

2 "Stefan cel Mare" University, Faculty of Economics and Public Administration, Department of Accounting, Audit and Finance, Romania, ORCID: 0000-0001-6378-6686, marians@seap.usv;

3 "Stefan cel Mare" University, Faculty of Economics and Public Administration, Department of Accounting, Audit and Finance, Romania, ORCID: 0000-0002-8560-9223, mariusc@seap.usv.ro;

4 "Stefan cel Mare" University, Faculty of Economics and Public Administration, Department of Accounting, Audit and Finance, Romania, ORCID: 0000-0003-2465-4722, veronicag@seap.usv.ro;

5 West University of Timişoara, Faculty of Economics and Business Administration, Department of Accounting, Romania, ORCID: 0000-0001-7158-8794, dorel.mates@e-uvt.ro.
}

\begin{abstract}
The accelerated pace of economic development, the digital revolution and the internationalization of business has meant for some entities the creation or acquisition of intangible assets (IA), which have become increasingly important for the economic prosperity and for determining the global value of a company, also becoming an important incentive in creating added value. The aim of this paper is focused on analyzing the impact of internally generated intangible assets on the market value of the companies. In order to achieve this aim, we conducted an empirical study involving a sample of 180 NASDAQ and NYSE listed entities between 2007 and 2016. The sample has obtained by applying the inclusion and exclusion criteria on the 500 large-capitalization companies (S\&P 500 Index). Making use of regressive techniques, the authors undertook an econometrical model to test whether the impact of intangible assets on the market value of the entities increases when are provided complete, clear and easy-to-understand accounting information about the intangible assets value, which aid business to properly estimate corporate value ratio and reduce implicit bias, due to mainly taking into account those reported values when measuring an entity's value. The results revealed an impact of the value of the reported and unreported IA on the market value of the entities, for manufacturing companies relative to service companies, which generates an added value on the capital market and implicates a close linkage of disclosure compliance and the associated industry sector. The proposed model can be an inspiration for the legislator to change the structure of financial reporting, or anticipated a valuable informational source for increasing the quality of integrated reporting of economic entities.
\end{abstract}

Keywords: Internally generated intangible assets, valuation, book value, market value, econometric model.

JEL Classification: M41.

APA Style Citation: Cosmulese, C. G., Socoliuc, M., Ciubotariu, M.-S. Grosu, V., \& Mateş, D. (2020). Empirical Study on the Impact of Evaluation of Intangible Assets on the Market Value of the Listed Companies. E\&M Economics and Management, 24(1), 84-101. https://doi. org/10.15240/tul/001/2021-1-006 


\section{Introduction}

The shortcomings in traditional financial reporting have become more than obvious, if we look at the results of different researches or studies in the field, but especially according to the thesis supported by Robert Eccles, from Harvard Business School, which shows that only $25 \%$ of the market value of a company can be attributed to its accounting value, the rest of $75 \%$ coming from the evaluation of the value created by IA (such as strategies, product innovation, customer loyalty, future profits, goodwill, etc), which are fully accounted for only extraordinary events, such as acquisitions and mergers of companies, or the sale of their subsidiaries (Eccles, 1991). Thus, only a small part of the factors that contribute to the creation of value are identified and presented in the reporting used by investors, which obviously creates an obstacle in understanding the mechanisms of value creation, taking into account the strategic importance of IA.

According to the above, some years later, in a report of the International Integrated Reporting Council (IIRC) it is shown that the share of IA would have reached much higher values, in the sense that the tendency to increase the weight of intangible assets registered from 1975 to 2009 , compared to the market value of the companies included in the S\&P 500 Index, it went from $17 \%$ in 1975 to among 80 and $81 \%$ between 2005 and 2009 (IIRC, 2011). Some of these assets are presented in the financial statements, but another important part is not included, which practically compromises the accuracy of the information provided by this type of reporting.

Therefore, it becomes increasingly burdensome for an entity to maintain a level of competitiveness in the modern, globalized world, which no longer relies on tangible assets. In this context, we start from the premise that the economic doctrine, normally identified by a paradigm of structure and adapted to the requirements of these structures, nevertheless presents a limit when it fails, to explain why the companies that operate in the same sector and who follow similar strategies, still obtain results that are not identical. What exactly makes the company more efficient than the other, even if it operates in the same sector and follows the same startup? However, there is the theory of resources and competences, consolidated since the late 1980 s that provides a timely answer to this question (Barney, 1991, 2001). The differences in results between companies belonging to the same sector and with similar strategic behaviors consist in the superior endowment of the distinctive resources and competences or in the possession, for each company, of those tangible and intangible assets that are difficult to imitate or reproduce by other subjects (Badicu \& Mihaila, 2016).

In the current context, it is even more necessary not only to develop distinct skills, such as "having knowledge" and "knowing how to apply these know-how", but also to make them visible by making them explicit in the economic and social system to which they belong. In fact, intangible resources are increasingly considered the foundation of the company's competitive power, as it plays a key role in creating competitive advantages (lancu et al., 2014; Mihaila, 2014; Burciu \& Kicsi, 2015). For this purpose, we will examine the generally recognized criteria and an accepted doctrinal level for the identification and classification of intangible assets, but also a review of the criteria for evaluating and recognizing these resources in financial statements, as well as those that are difficult to identify or separate from the other assets that remain outside the balance sheet. Therefore, the aim of the paper is focused on creating an econometric model for evaluating the value of internally generated intangible assets and including these values in the traditional reporting of economic entities, as this discrimination treatment between companies producing $\mathrm{IA}$ and those that purchase still exist. In order to achieve this aim, the following objectives have been set:

1. To analyse and systematize recent literature on the intangible assets;

2. To identificate and evaluate impact of internally generated intangible assets (IGIA) on the market value of companies;

3. To identificate and discuss the main solutions or proposals regarding the extension of the structure of the balance sheet that also includes the value of unreported internally generated intangible assets (UIGIA).

The structure of the paper: in the first section of paper, the literature review on the intangible assets and its impacts is provided, followed by the research methodology who presents an descriptive and analytical approach, through which we want to develop a tool for testing hypotheses and validating 
the results that can finally be accepted by the academic, practitioners and legislators. In this section are also described the dependent and independent variables selected. The structure continues with the results analysis that provides the empirical results and implements various robustness checks for the validity of the benchmark findings. The study ends with a conclusion of the findings of the study, as well as observations on their limitations.

\section{Literature Review}

Currently, companies are turning to the generation and development of unique assets that, although present a high risk, are meant to guarantee the sustainability of the entities that own them. Scientific studies (Ocean Tomo, 2015) show that the market value of the entities is much higher than the book value, this discrepancy serving as proof that the assets that are not reflected in the entity's balance sheet play a major role in generating corporate wealth. An in-depth study of the specialized literature shows us a continuous concern of the researchers, but also of the bodies responsible for developing the standards regarding the assessment and recognition of IA in the assets of listed or unlisted entities, many of them (Grosu, 2013; Salameh \& Bashir, 2013; Bunget et al., 2014) claiming that the identification and recognition of all types of IA has not yet been sufficiently investigated and therefore their estimation is considered a complex task, and can be determined as the difference between the real value (market value) and the current (book value) of an economic entity. Although various methods of valuing intangible assets are created or proposed (Smith \& Parr, 1994; Surroca et al., 2010; OECD, 2012; Gamayuni, 2015; Pastor et al., 2017), their application in practice or in empirical studies is difficult to materialize.

Maintaining a competitive advantage over the other competitors and increasing the stock market value of the shares is determined by the real value of the IA, both reported and unreported (Smalt \& McComb, 2016; Bužinskienè, 2017; Lampinen, 2018). This hypothesis is confirmed by numerous studies in the field (Nonaka \& Takeuchi, 1995; Bontis, 1998; Lev, 2001; OECD, 2008; Volkov \& Garanina, 2008; Nakamura, 2010; Greco et al., 2013; Chen et al., 2016; Clausen \& Hirth, 2016; Jordao \& de Almeida, 2017; Osinski et al., 2017; Fejes, 2018) who argued that current accounting treatment applied to intangible assets does not help to reflect the real value of IA, and implicitly the value of the entity. Moreover, it presents gaps and shortcomings that have reduced over time the relevance of the financial statements, an aspect due to the continuous increase of the value of IA and at the same time the limitations regarding their recognition.

In the last decades the need for improvement or extension of the structure of financial statements with new information, significant values for the reporting entity, has been increasingly felt (Cosmulese et al., 2019) In these circumstances, it is inevitable not to ask ourselves: what would be the limits of reporting internally generated intangible assets? As we mentioned in the first part of the paper, IA represents those elements that confer a central position in explaining the success of a company and which explains why the entity is not only an organized system that purchases inputs, but transforms them and transfers them to the market having incorporated a certain level of added value.

Judging from the analysis of the numerous studies carried out in the field, the perceptions differ according to the purpose of the studies. For example, part of the international IFRS referential only those intangible assets which are non-monetary and are different from the other assets can be identified and reported in the balance-sheet at a justified cost (IAS 38, Active intangibile, paragraph 8-17; IFRS 3, paragraph 12). Yet, there are some authors who recommend extending the capitalization of internally generated intangible assets by adjusting their recognition criteria, while others call for a fundamental change in the traditional accounting model, towards a full assessment/reassessment of the entire set of assets at fair value, which would be more able to reflect the value of IA (Skinner, 2008). Also in this context, we consider that, besides the characteristics or nature of the company, the characteristics of the various industries to which the company reports affect the degree of disclosure of the intangible assets, one of the factors that could affect the relative bargaining power of the entity, is the degree of industry concentration. When an industry is fragmented and concentration is low, competition in the industry is probably more intense and the bargaining power of the firm is low. Therefore, 
Anderson et al. (2004) indicate that a higher concentration may provide more market power, which may lead to higher intangible assets. In this regard, Rao et al. (2004) examining the link between intangible assets and leverage, finds that entities with higher growth opportunities have a low leverage value. However, previous studies (e.g. McConnell \& Servaes, 1990) show that firms with high leverage can enjoy a fiscal advantage. They can deduct interest costs, which results in a larger cash flow and thus imply a positive relationship with intangible assets. The intensity of capital also affects the value of intangible assets, as it is a proxy for investment opportunities.

Although since the 90 s the interest of academics on the topic has exploded, the researchers have not been able to provide an effective and concrete method/method of evaluating the IA that could determine the legislator to allow entities to report this value through the balance sheet, thus contributing to the elimination of discrimination between the entities that produce these types of assets and those that purchase them (Bareja et al., 2017). The vast majority of researches have promoted research procedures or plans that have limits, because they are not feasible in pragmatic terms, in other words they do not justify their applicability at the level of an economic entity, either because they could be too expensive or because of the avalanche of information does not justify its usefulness to the stakeholders of the entity (Zhang, 2013; Podhorska \& Siekelova, 2016; Novák, 2018).

In conclusion, we can say that the concern and the increased interest for this topic in the academic environment are obvious, which is why we considered it appropriate to continue these challenges by identifying new problems that remain unresolved and proposing appropriate solutions.

\section{Research Methodology and Data}

\subsection{Research Purpose and Hypotheses}

As described in the previous sections, this study aimed to analyzed the impact of internally generated intangible assets on the market value of the companies by creating an econometric model in order to include the values of reported and unreported intangible assets in the traditional reporting of economic entities, as this discrimination treatment between companies producing IA and those that purchase still exist.
In order to reach the proposed objective, the following research hypotheses $(H)$ have been established:

H1: The impact of the value of intangible assets generated internally and not reported on the market value of economic entities is greater than the value of the intangible assets reported.

H2: The higher the value of a reported intangible asset (RIA), the greater the impact on the entity's market value.

H3: The impact of the value of the reported and unreported intangible assets on the market value of the entities is stronger for manufacturing companies relative to service companies.

H4: As the global value of intangible assets increases, the market value of the entities increases.

This assumption is based on the fact that all changes in value that are associated with the provision of new accounting information to the external market/environment depend on the accuracy of the information, which reports the total value of the intangible asset.

\subsection{Sample Selection}

In order to carry out the empirical research, in the phase of collecting the necessary information, we used mediated data collection techniques, using information from the annual financial statements and the administrators' reports published on the official websites of each entity in the analyzed sample Standard \& Poor's 500 Index (SPX), but also from secondary sources, through specialized portals on scholarships, such as the Gurufocus.com screened playback site. Other data used were obtained by calculations and own processing, following the application of statistical-mathematical methods, using MS Excel software.

The study sample is composed of 180 NASDAQ and NYSE listed entities between 2007 and 2016, selected on the basis of inclusion and exclusion criteria from the 500 large-capitalization companies (S\&P 500 Index), the sample being heterogeneous in the sense that it was not kept account of the field of activity, the type of market or the geographical area on which these companies operate. Regarding the inclusion criteria, they mainly focused on: the primary character of the information - only intrinsic and representative indicators were introduced in the study to generate the model; homogeneity of data - only information on indicators with a high degree of 
homogeneity has been introduced in the study to allow representative outputs to be obtained; connection with the market - quotation indicators were introduced in the study to allow the analysis of the impact of IA on the market value of the holding entities; reflection after financial reporting of IA - elements were introduced into the study to highlight the effect of goodwill on the market value of the company. The exclusion criteria imply: the entity's affiliation with the banking activity; lack of IA reported from annual financial statements; the principle of continuity of quotation (maintaining the market for the whole period analyzed); atypical behaviors regarding capital policy; problems of return of assets with low yield.

After applying the selection criteria, namely, the possibility of calculating the 17 indicators initially selected for modeling, 180 listed entities remained in our portfolio, most of them grouped into sectors such as: energy, health, motors vehicles and parts, technology, telecommunications and the food, beverage and tobacco sectors. The collection of information was a challenge for the present research, as the financial data, those regarding the IGIA were manually calculated.
The sample taken into account (180 S\&P 500 companies) is representative for the proposed objective, namely: the analysis of the impact of IGIA on the market value of the holding entities, as it represents $36 \%$ of their total number.

The structure of the sectoral sample was analyzed according to the accumulations of IA reported in the balance sheet - IA associated with financial information/reported internally generated intangible assets (RIA/RIGIA), noting that the classification is not a relevant one because they must be viewed in correlation with the accumulations of tangible assets, the size of the entity's capitalization being very different depending on the sector of activity, or in relation to its profitability, which represents the main purpose of the employers and the management of the companies. From the analysis of the structure of the sectoral sample according to the accumulations of capital, it is noted that in the telecommunications and energy sector the accumulations of equity exceed the average of the general accumulation, which means that the entities in these sectors predominantly base their activity on the exploitation of IA and numerous personnel resources. The analysis

\section{Fig. 1: Structure of the sampling on sectors of activity}

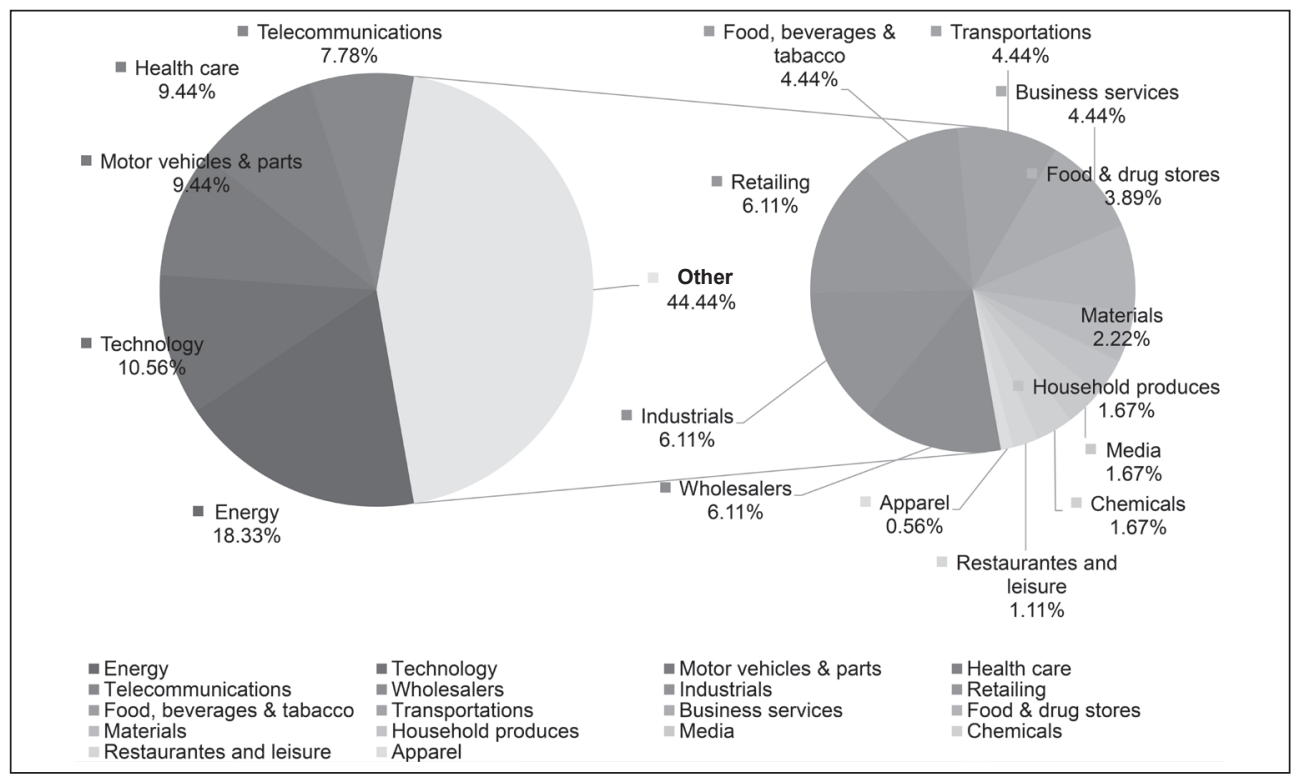


of the sample according to the average value of the shares, shows us that in terms of stock quotes, the most attractive companies are those that offer business services (consulting), the IT sector and the public food sector. The reasons for the high quotation value are strictly related to the profitability of the business which, in the case of consulting services or IT services, is very high in relation to the costs involved in the business, and in the public food sector, this profitability results from the fact that the market is extremely large, the field of activity addressing to the satisfaction of a primary need such as the need for food, for which there is a potentially unlimited demand.

Thus, the diagram of the sample representativeness in terms of RIA intangible assets reported in the balance sheet is presented in Fig. 1.

\subsection{Variables Used, Data Processing and Results}

As regards the variables used, firstly we describe the dependent variable and then we define the independent variables considered appropriate for the development of this empirical study.

The empirical data needed for this part of the study were collected using the random sampling method and the content analysis method. A major difficulty in preparing the regression model was the selection of a variable that would capture the isolated effect of UIGIA. Therefore, within this line of analysis it is expected that a smaller percentage of the intangible assets registered in relation to the total assets will result in a higher return on the assets, because the total assets are undervalued (through the absence of UIGIA), and in the companies where there are already registered (acquired) relevant IA, they will reduce the return on assets (ROA). In this context, we developed a "proxy" - Internally Generated Intangible Assets (IGIA), calculated as follows: market value of equity at the balance sheet date minus the book value of equity plus the book value of IA recorded in the balance sheet.

In order to highlight the variables attributed to the difference between the market value and the accounting value of a listed entity, we will resort to a synthesis of the variables that, according to the specialized literature, influence the IA and implicitly on the market value of the entity and also provide a brief explanation of them, from a theoretical point of view, considering the calculation method and their connection/ correlation with the intangible assets.

In order to determine the impact of IGIA on the market value of the coiled entities, four econometric models with a determined unitary dependent variable and similar instrumental variables were elaborated, testing the homogeneity of the model being performed by fixing different regressors. For the elaboration of the econometric models, we crystallized the model equations for IGIA, as follows:

$$
\begin{aligned}
& I G I A_{i t}=\alpha_{0}+\beta_{1} T D_{-} A_{i t}-\beta_{1} T A_{-} A_{i t}+ \\
& +\beta_{3} \text { Capitaliz }_{i t}+\varepsilon_{i t} \\
& I G I A_{i t}=\alpha_{0}+\beta_{1} G P_{i t}-\beta_{1} T_{i t}+\beta_{3} N I_{i t}+\varepsilon_{i t} \\
& I G I A_{i t}=\alpha_{0}+\beta_{1} R \& D \operatorname{Dexp} p_{i t}-\beta_{1} A S P_{i t}+ \\
& +\beta_{3} E V_{i t}+\varepsilon_{i t} \\
& I G I A_{i t}=\alpha_{0}+\beta_{1} E B I T_{i t}-\beta_{2} E_{B I T D A_{i t}}- \\
& -\beta_{3} R O E_{i t}-\beta_{4} R O I C_{i t}+\beta_{5} R O A_{i t}+\varepsilon_{i t}
\end{aligned}
$$

Thus, for the calculations of the models the dependent variable was taken into account: IGIA = Internally Generated Intangible Assets, this being tested in relation to the regressors: TD_A = total debts adjusted, recorded at the balance sheet date; TA_A = total adjusted assets, recorded at the balance sheet date; Capitaliz = market capitalization; $\mathrm{T}=$ turnover; $\mathrm{GP}=$ gross profit; $\mathrm{NI}=$ net income; R\&Dexp = research and development expenses; $A S P=$ the average trading price of a share; $\mathrm{EV}=$ the value of the enterprise; $\mathrm{EBIT}=$ Earnings before interest and taxes; EBITDA = Earnings Before Interest, Taxes, Depreciation and Amortization; ROE = Return on equity; ROIC = Return on invested capital; ROA = Return on Assets.

Considering the multiple linear regression models, defined by the relationships above, we verified during the research paper the following hypotheses that must be respected in order to perform statistical modeling (Jemna, 2012):

Independent variables: T, TA_A, TD_A, Capitaliz, NI, ASP, ROA, ROIC, ROE, EBIT, EBITDA are non-stochastic;

1. $M(\varepsilon)=$ constant $=0$;

heteroscedasticity $\mathrm{V}\left(\varepsilon_{\mathrm{i}}\right)=\mathrm{M}\left(\varepsilon_{\mathrm{i}}^{2}\right)=\sigma^{2}$;

2. Normality of errors, $\varepsilon_{i} \sim N\left(0, \sigma^{2}\right)$;

3. Non-correlation of errors, $\operatorname{cov}\left(\varepsilon_{i}, \varepsilon_{j}\right)=0$;

4. Lack of correlation between the independent variables and the error variable,

$\operatorname{cov}\left(\varepsilon_{i}, X_{1}\right)=\ldots=\operatorname{cov}\left(\varepsilon_{i}, X_{9}\right)=0$; 
5. There is no linear connection between the independent variables.

\section{Research Results}

Following the collection of relevant data, in order to obtain relevant results and at the same time to deepen the proposed topic, a series of indexes and scores corresponding to each variable were created, which subsequently helped to complete the multiple regression equations. The data thus obtained were analyzed using the statistical software program GRETL version 2019d.

In order to verify the reliability of the optimal model proposed, for those variables, which were included in the multiple linear regression model, we applied statistical tests as well; dispersion, adjusted dispersion, student test, heteroskedasticity, Pearson coefficients and Akaike criteria, Schwarz and Hannan-Quinn criteria, which demonstrated the reliability of the model by the valid values obtained.

Given that internally generated intangible assets (with the exception of those assets acquired as a result of a separate acquisition or business combination) are not recognized in the balance sheet, to capture those internally generated intangible elements that influence the value of the entity decisively and significantly a proxy, named by us - UIGIA. Note that in previous studies various proxies were used. For example, Gu and Wang (2005) use research and development expenses, advertising expenses and intangible assets acquired in this respect, while Barth et al. (2001) added other depreciation expenses. However, our study focuses on the capitalization of intangible assets and therefore we want our results to be comparable to those of Matolcsy and Wyatt (2006) and Chalmers et al. (2012), which is why we choose to use a proxy proposed by them, which is through the formula: the market value of equity minus the book value of equity plus intangible assets capitalized in the balance sheet. We mention that there are several studies that support the use of this calculation formula (Chung \& Pruit, 1994; Smith \& Watts, 1992).

As can be seen from above, some of our proxy values for IGIA are negative, which was the case in previous studies using the same proxy (i.e. Matolcsy \& Wyatt, 2006; Chalmers et al. (2012). Although negative values regarding the value of intangible assets generated internally for a company are not theoretically plausible, Matolcsy and Wyatt (2006) explain that these negative values are most likely the result of a decrease in market value that preceded the impairment of intangible assets for the observed entity. As I mentioned earlier, for entities with higher levels of IA, analysts should benefit the most from the potentially important information that can be attributed to the capitalization of these assets. From our analysis it can be observed that out of 17 independent variables, only 4 variables are closely correlated with the IGIA, namely: Capitaliz, T, GP, NI, OP (operating profit). These four variables have a strong influence on the dependent variable, between IGIA and T having a directly significant connection of 4.93-E06. We also observe that, a standard deviation of the $\mathrm{T}$ against the average value is $1.60 \%$, in exchange for the variables EV, S_N, the deviation is higher $3.16 \%$, respectively $\overline{9} .38 \%$.

In order to elaborate the empirical research, we used a modern and complex proxy for quantifying intangible assets not recorded in the balance sheet, which we called IGIA. The value of intangible assets generated internally and unrecorded (IAGIU) in the balance sheet was determined as the difference between the market value of the entity and the net book value of the entity (or total assets minus total liabilities minus IA recorded in the balance sheet). In order to improve the comparability between the studies performed so far and the robustness of our tests, we will adopt the estimation method Two-Stage least squares (2SLS), the method of smallest squares in two phases, which allows us to estimate the unique structural equation that interests us, without modeling explicitly the entire relationship of the system, that causes simultaneity. To perform this regression we used a set of instrumental variables that are correlated with the regression variables and not correlated with the perturbations (Greene, 2000).

From the analysis of the independent data, namely the t-statistic for model 1 and 3 , we find that the variables Capitaliz and EV have a significance of 4.5301 and 7.303 respectively, with a significance below 0.1 compared to the IGIA index. This means that each internally generated intangible asset has a strong connection with the appreciation of the market value. As can be seen, the negative codes of the statistical coefficient $t$ of the variables: 
TA_A, T, ASP, show that the average of the independent variable is lower than the average of the dependent variable. This result has the same value as the research from Garanina and Pavlova (2011), in which they found that the intangible value has a positive correlation with the market value index. Even ROE, ROIC, ROA, EBITDA and EBIT have a negative relationship, but the value of the error is not significant. The structured analysis allowed us to perform preliminary calculations for the econometric model generation, based on which it was possible to determine the estimated equation of the multiple linear regression model for IGIA. Thus, it can be seen that the first model is the most significant/optimal with R-squared $=0.846$, in which we made a correlation between the capital elements, the stock market capitalization, the quantification of the shareholders' contribution to the share capital level, and the goodwill elements capitalized in balance sheet, all of which ultimately indicate the impact of IA on the value of listed entities as being significant and which generates an added value on the capital market. In the case of the other models, their $\mathrm{R}^{2}$ value is below the limit of 0.6 - a value that allows us to state that, the models have not been well specified (applying the method of the smallest squares in two phases, an analysis technique that has the statistical program GRETL version $2019 d$, in the case of regressions regarding the IGIA dependent variable, was obtained a series of estimated values for each of the 4 models.

It can be observed that, in the case of model 1 , the value of the coefficient of determination $R^{2}$ is 0.846 (calculated as the square of the correlation coefficient and represents the variant weight from the internally generated intangible assets, explainable through the model equation), which shows that the regression equation explains/ describes in proportion of $84.59 \%$ the variation of the dependent variable and of the whole phenomenon. This percentage is a consistent one that attests to the model's credibility and impact on the research theme, a fact reinforced by the value of the adjusted correlation coefficient that falls within the same confidence limit of $84.42 \%$. In contrast, in the case of models 2 and 3 , we can see that $R^{2}$ explains in a much smaller proportion the phenomenon: $26.45 \%$ and $52.06 \%$ respectively. Regarding the result of model $4\left(R^{2}=3.5 \%\right)$, we affirm that, one of the reasons why it has an insignificant value, it may be due to the fact that the coefficient of determination $\mathrm{R}^{2}$ oscillates with respect to its value as we include more many variables in calculating the dependent variable.

In the case of model 1 and 3 , the analysis of the variance shows that the average of the dependency variable is higher than the standard deviation. Regarding the dispersion $\mathrm{R}$, this indicator is a valid one, given that its limit tends to 0.0 , for model 1 , this condition is fulfilled. Since the values F-statistic and Prob (F-statistic), in the case of the first model are 111.08 respectively $-19,502.26$, this fact attests that the model significantly influences the dependent variable, therefore we accept the model as the most appropriate. The values found in the F-statistic and Prob (F-statistic) law, for model 3, are significant 49.84493, respectively $-15,667.86$, which denotes that, from the point of view of the statistical test, we assert that this model is also appropriate. Models 2 and 4 do not comply with the decision rule regarding the acceptance of the model (the F-statistic has the highest values, and the Prob (F-statistic) the lowest values), which is why we consider them to be inadequate. The Akaike criteria, the Schwarz criterion and the Hannan-Quinn criterion are used to determine the consistency of the model data by comparison with another possible model, in our case the value associated with the model representativeness indicated by the square $R^{2}$ test which leads to the statistical validation of the model 1.

Before performing the regression analysis, a Hausman test was performed to decide whether the regression of fixed or random effects was used. In this sense, it is tested whether the unique errors are correlated with the regressors; the null hypothesis being that they are not correlated (Greene, 2000). Therefore the asymptotic value of the Hi-square test in correlation with the p-value that falls, if we refer to the model 1 , in the interval $[0,1](p$-value $=0.14742)$, indicates that the regression of the fixed effects is actually the one better method of data analysis, meaning that the model is well defined, consistent and homogeneous.

The test for the null hypothesis of the normal and square distribution for model $1(=0.03>0$, and its p-value of 0.974$)$, indicates that the statistical series falls within the reference 
range $[0,1]$, which means that the model is well defined, consistent and error-free. Within these statistical determinations the 95\% confidence interval was calculated and the test was valid.

The statistical test for the normality of the residue indicates values of the distributed errors, under the conditions of a p-value that falls within the reference range $[0,1]$. Thus, model 1 is confirmed to be constituent and without significant errors. At the same time, the test of inconsistent variables related to model 1 indicates a value close to 0 , which confirms the homogeneity of the model.
From Fig. 2 we can observe a homogeneous distribution and a corresponding winding of the value around the forecast step related to model 1 . The amplitude of the winding reflects the homogeneity of the model data. By using statistical modeling, a set of econometric correlations was obtained whose values generate the estimation of the linear relationship between the dependent variables and the defined independent variables. The model was developed based on the method of the smallest squares, in two phases. The confidence interval is a representative one, and

\section{Fig. 2: The $Q-Q$ plot diagram for the regression models}

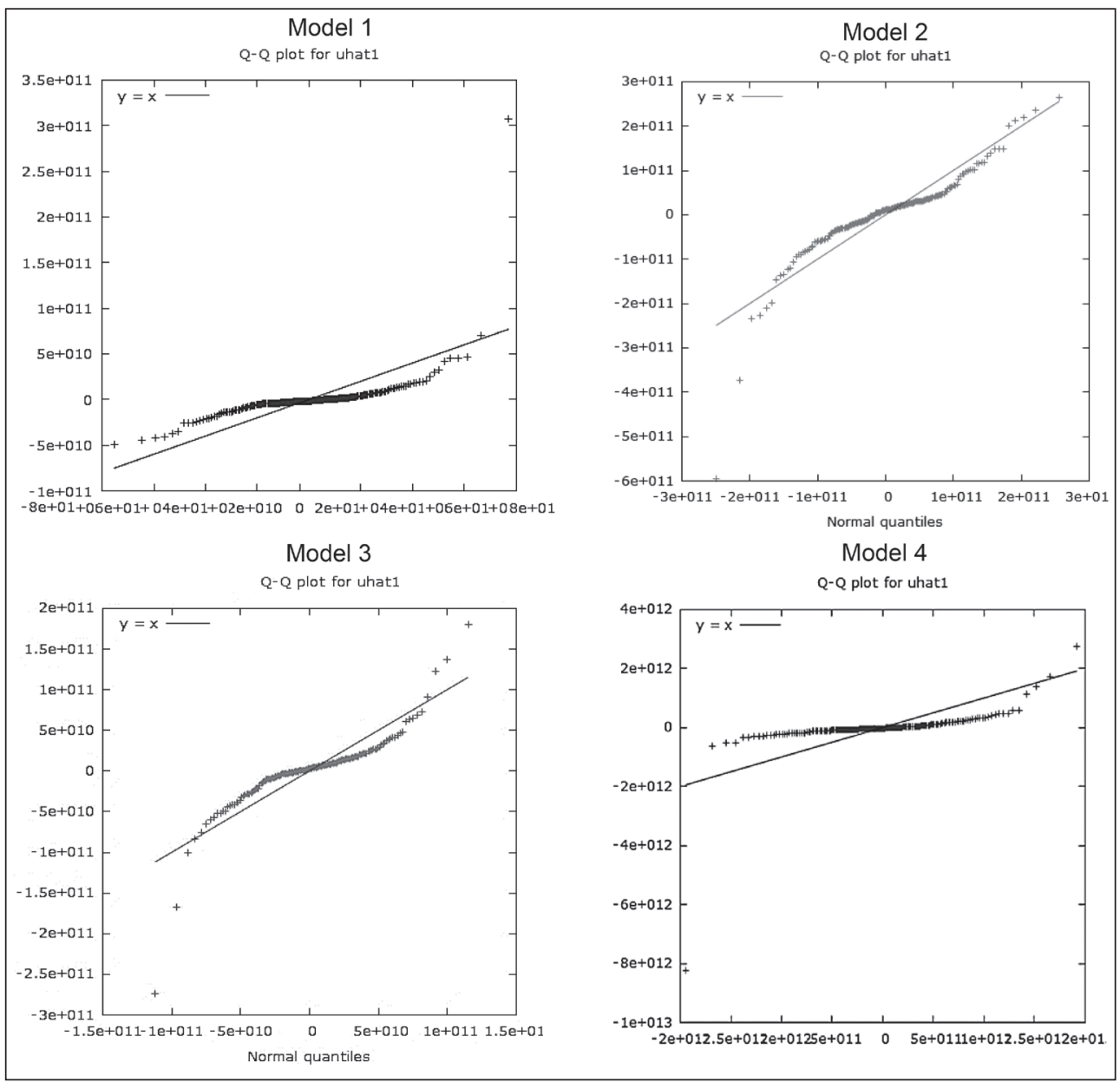

Source: GRETL version 2019d 


\section{Fig. 3: Forecast chart}

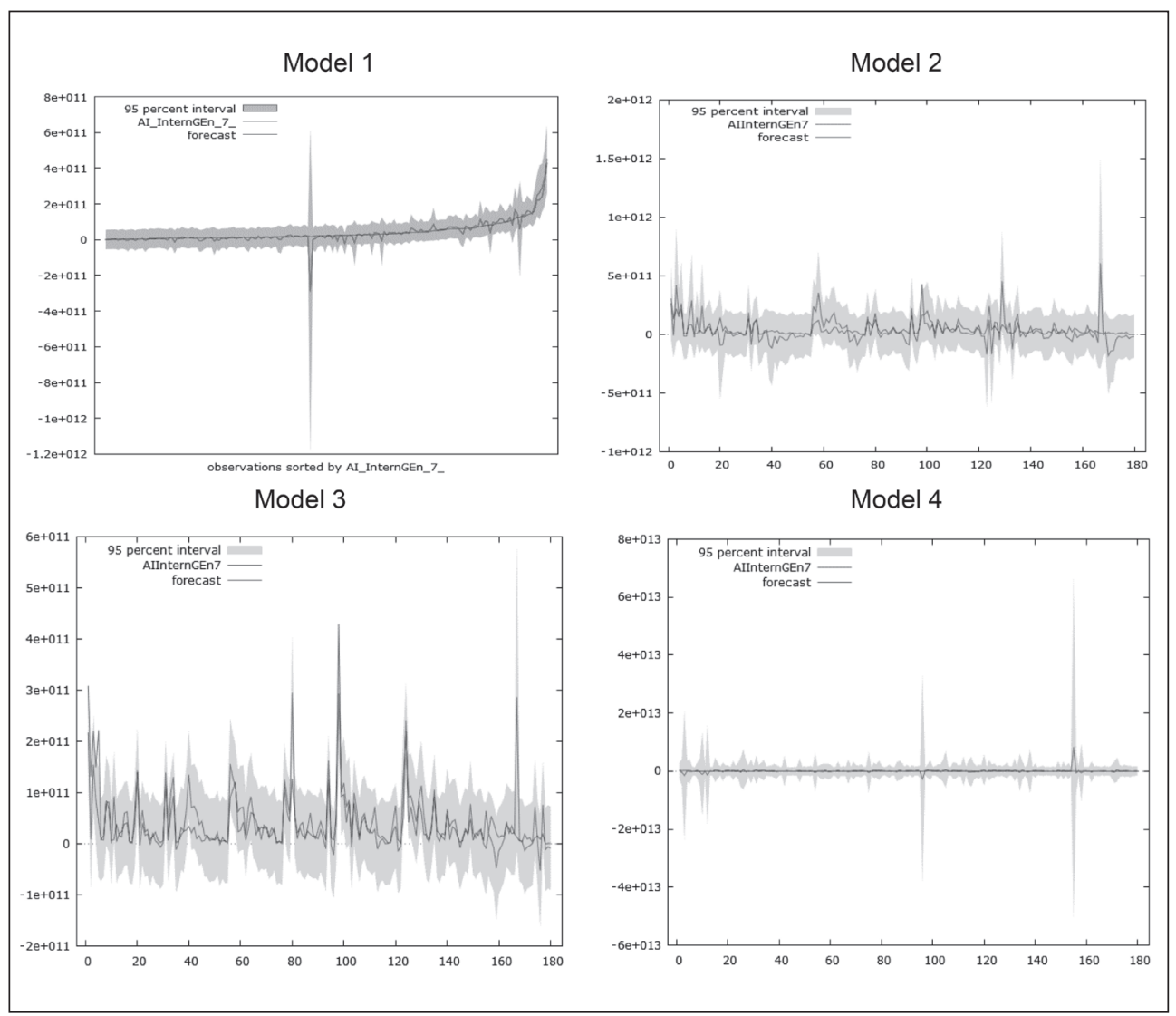

Source: GRETL version 2019d

the estimates of the dependent variable are considered efficient, so the relationship graph on the $Q-Q$ plot diagram indicates a normal distribution of the value of the variables, which means that they contribute correlated to quantifying the impact of IGIA on the market value of listed entities. The heteroskedasticity accounting method reflects the endogeneity of the econometric model, validating practically the regression model 1 . Heteroskedasticity occurs if the errors or the residual value of the observed model does not have a constant variation on one observation compared to another observation. This indicates that each observation has a different reliability due to changes in the background conditions that are not summarized in the model specification.
Based on the forecast graph (Fig. 3) we can determine the evolution trend with a function representation of 0.95 , which means that the phenomenon has a dynamic considered predictable and evaluated according to the parameters defined in the model.

The presented histogram allows us to see "at a glance" how the analyzed statistical events are distributed. Thus, as can be seen from Fig. 4 in the case of model 1 , the statistical test of normality shows the agglomeration of data in the quartile area, highlighting that there is a strong relationship between the variables, the causal relation being reflected in the effective possibility of quantifying the studied impact. Therefore, we reinforce the idea stated above, namely: the assumptions of normality are not contradicted, 


\section{Fig. 4: Error histogram/frequency curve of the regression model for IGIA}

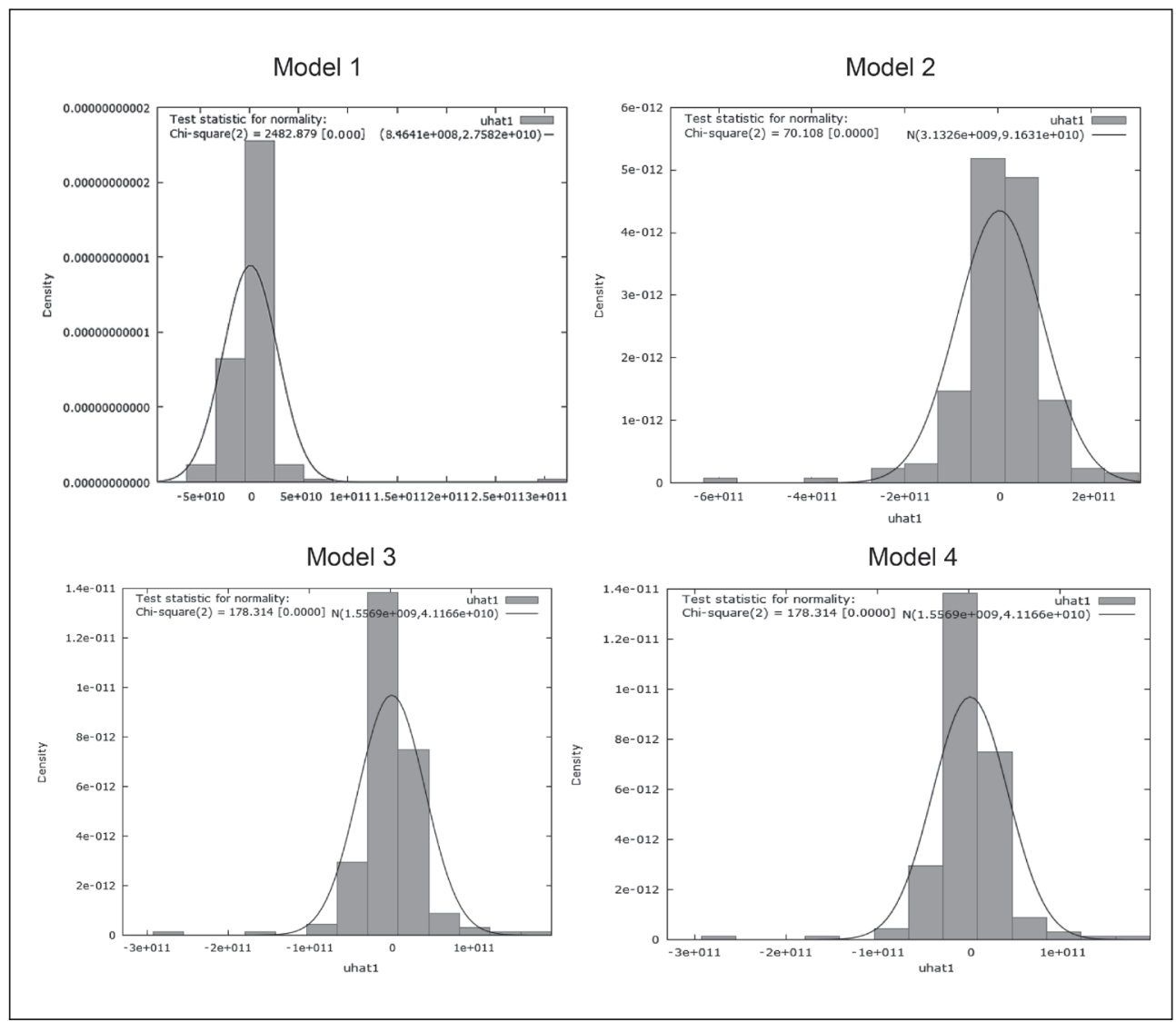

Source: GRETL version 2019d

Note: Frequency distribution for the dependent variable, obs 1-180.

the distribution having a bell-like appearance. Of the four models elaborated, it was found that model 1 is the most representative for evaluating the impact of intangible assets generated internally on the value of listed entities, given that the statistical test $R^{2}$ reflects a value of representativeness of $84 \%$, much higher than the other 3 models analyzed. Therefore, based on the observational study, we proceeded under the conditions of hypothesis number 3 when structuring the database into two lots according to the selection criterion of activity, manufactoring or services sector.

The results were econometrically modeled using the model variable, obtaining statistical tests of representativeness and homogeneity of the model on the two distinct sectors. Thus, the dissemination of the results is presented in Tab. 1.

Previous studies (Bužinskienè, 2017; Glova \& Mrázková, 2018; Swanson, 2018) have pointed out a difference in the value of IAs of companies between financial and non-financial information. This study, however, shows that the impact of the value of the intangible assets generated internally and unreported on the market value of the economic entities is greater than the value of the intangible assets reported. Thus, $\mathrm{H} 1$ is confirmed, this fact being due to the investors, although they do not have direct access to the value IGIA through financial 


\section{Tab. 1: Quantifying the impact of the IGIA value on the market value of the listed entities by activity sectors}

\begin{tabular}{c|c|c|c|c} 
No. & Indicators & $\begin{array}{c}\text { Consolidated version } \\
\text { model 1 }\end{array}$ & Manufactoring model & Services model \\
\hline 1. & $\mathrm{R}^{2}$ & 0.846 & 0.932 & 0.688 \\
\hline 2. & $\mathrm{R}^{2}$ adjusted & 0.844 & 0.55 & -0.128 \\
\hline 3. & P-value & $1.75 \mathrm{E}-40$ & $3.73 \mathrm{E}-24$ & $4.06 \mathrm{E}-14$ \\
\hline 4. & Hausman test & $\begin{array}{c}\text { OLS estimates are } \\
\text { consistent }\end{array}$ & $\begin{array}{c}\text { OLS estimates are } \\
\text { consistent }\end{array}$ & $\begin{array}{c}\text { OLS estimates are } \\
\text { consistent }\end{array}$ \\
\hline 5. & Conclusions & $\begin{array}{c}\text { Homogeneous model, } \\
\text { well determined and } \\
\text { representative as } \\
\text { a percentage of } 84.6 \%\end{array}$ & $\begin{array}{c}\text { Homogeneous model, } \\
\text { well determined and } \\
\text { representative in } \\
\text { percentage of } 93.2 \%\end{array}$ & $\begin{array}{c}\text { Homogeneous model, } \\
\text { well determined and } \\
\text { representative in } 68.8 \%\end{array}$ \\
\hline 6. & Impact & Strong & Maximum & High \\
\hline
\end{tabular}

Source: own based on data processed using GRETL version 2019d

reporting, this information can be deducted from the sale price of the shares. In addition, it is likely that the value of the IA associated with the non-financial information and that enters into the calculation of the market value of the entity, will decisively determine only value increases. We consider that the investors' reaction to the value of the unreported intangible assets, but recognized by the stock market capitalization indicator can be manifested in different forms: either directly or indirectly. This is because although investors do not have direct access to their value through financial reporting, this information can be deducted from the sale price of the shares. If IA associated with financial information (RIA) are measured at historical cost, and IA associated with non-financial/ internally generated information (IGIA) are valued at market price, it follows that RIA is a lower part of intangible assets (RIA < IGIA).

Regarding $H 2$, namely: the higher the value of RIA, the greater the impact on the market value of the entity, the results indicate that $58 \%$ of the cases have an average impact superunitarian, and for $42 \%$ the average impact is subunit, therefore the working hypothesis is validated. The second hypothesis of the research confirms that any increase in the value of an RIA, compared to the previous year (even if there are quite small increases), will have a greater impact on the impact of the entity's market value (see Tab. 2).

The analysis on dynamic data series $(n / n-1)$ for RIA and stock market capitalization indicates a significant impact (110\%) on the market value of the entities at a $100 \%$ increase of RIA. In fact, the analysis contains a significant sample of 661 observations for which the average impact is $144 \%$ and 837 observations for which the average impact is $88 \%$. From the statistical analysis it is shown that the hypothesis is confirmed for $58 \%$ of the cases, with a superunitary average impact, and for $42 \%$ the average impact is subunitary, therefore the working hypothesis is confirmed. When analyzing the changes in value of the IA reported and not reported / internally generated and their impact on the market value of the entities, the question arises whether the impact

Tab. 2: Impact of RIA growth on the market value of the entities

\begin{tabular}{l|c|c|c}
\multicolumn{1}{c|}{$\begin{array}{c}\text { RIA } \\
\text { Capitaliz }\end{array}$} & $>1$ & $<1$ & Total \\
\hline Remarks & 661 & 837 & 1,498 \\
\hline Impact & 1.44 & 0.88 & 1.16 \\
\hline Average impact & & & 1.095612 \\
\hline
\end{tabular}


of this asset depends on the activity field in which the entity operates.

If we refer to $H 3$, i.e. the impact of the value of the reported and unreported IA on the market value of the entities as being stronger in the manufactoring companies than in the service companies, the hypothesis is confirmed by the statistical tests, which indicate that the value of the coefficient of determination $\mathrm{R}^{2}$ is $93.2 \%$, for manufacturing entities and only $68.8 \%$ for those entities active in the field of services. These findings are in line with other international studies (see Novák, 2018) on disclosure of intangible assets, which show a better level of disclosure for manufacturing companies relative to service companies. When reporting accounting information is taken into account, the issue of transparency is often raised. Therefore, it is obvious that the value of the accounting information depends unconditionally on the disclosure of the information regarding the global value of the IA; in the conditions in which this is not desired there is the possibility to accentuate the informational asymmetry between management and investors. In this respect, the fourth hypothesis of the research follows, more precisely, as the global value of
IA increases, the market value of the entities increases.

The analysis on dynamic data series $(n / n-1)$ for RIA plus IGIA and the market capitalization for manufactoring entities indicate a significant impact $(141 \%)$ on the market value of the entities, at a $100 \%$ increase of the RIA plus IGIA. In fact, the analysis contains a significant sample of 168 observations for which the average impact is $210 \%$ and 149 observations, for which the average impact is $63 \%$. From the statistical analysis, it is shown that the impact is confirmed for $79 \%$ of the cases, with a calculated superunitary ratio. The analysis by series of dynamic data (n/n-1) for RIA plus IGIA and the market capitalization for entities with specific services indicate a significant impact $(127 \%)$ on the market value of the companies at a $100 \%$ increase of RIA plus IGIA. In fact, the analysis contains a significant weight of 610 observations for which the average impact is $184 \%$, and 580 observations for which the average impact is $65 \%$ (see Tab. 3). From the statistical analysis it is shown that the impact is confirmed for $74 \%$ of the cases, with a calculated superunitarian ratio. Thus, it turns out that, the impact of IGIA on the market value

\section{Tab. 3: Impact of aggregate value of RIA and IGIA on the market value of service and manufacturing entities}

\begin{tabular}{|c|c|c|c|}
\hline Manufacturing & $>1$ & $<1$ & Total \\
\hline Remarks & 168 & 149 & 317 \\
\hline Impact & 2.1 & 0.63 & 1.365 \\
\hline Average impact & & & 1.41 \\
\hline Service providers & $>1$ & $<1$ & Total \\
\hline Remarks & 610 & 580 & 1,190 \\
\hline Impact & 1.84 & 0.65 & 1.245 \\
\hline Average impact & & & 1.27 \\
\hline
\end{tabular}

\section{Tab. 4: Impact of IGIA growth on the market value of the entities}

\begin{tabular}{l|c|c|c} 
& $>1$ & $<1$ & Total \\
\hline Remarks & 778 & 729 & 1,507 \\
\hline Impact & 12.47 & 0.55 & 6.51 \\
\hline Average impact & & & 6.7 \\
\hline
\end{tabular}


of the entities is stronger in the manufacturing companies than in the service companies, which demonstrates the $\mathrm{H} 3$.

From the analysis on dynamic data series, it is confirmed in $96 \%$ of cases, with an average superunitarian impact, $\mathrm{H} 4$ according to which as the global value of the IA increases, the market value of the entities increases. The measurement of the impact of the value of the IA on the market value of the entities is treated from the theoretical and practical perspective as a result of the signals existing in these two areas. The present research does not aim to analyze the relations between the manager and the shareholder, the interests and/or the conflict situations; thus the ways of forming the capital structure, the policy of granting dividends and the existence of the informational asymmetry between management and the other users of financial information are not considered. The optimal model to be created includes changes in the value of reported information (RIA) and unreported/internally generated information (IGIA).

The analysis on the dynamic data series $(n / n-1)$ for IGIA and the market capitalization indicates a significant impact (670\%) on the market value of the entities, at a $100 \%$ increase of IGIA. In fact, the analysis contains a significant weight, namely a sample of 778 observations for which the average impact is $1,247 \%$ and 729 observations for which the average impact is $55 \%$ (see Tab. 4). From the statistical analysis it results that the hypothesis is confirmed for $96 \%$ of the cases, with an average unitary impact, and for $4 \%$ the average impact is subunit, therefore the working hypothesis is confirmed. We emphasize the idea that, as a result of the theoretical arguments, the opinions of authors devoted to the main topics and topics of the research, together with statistical and economic-statistical arguments, each of the 4 hypotheses stated is confirmed.

Going through the analysis stages we can say that, only one of the four models of multiple linear regression developed has been validated, it is correct and can be used to analyze the evolution of the independent variable: IGIA and not reported in the annual financial statements. Thus, the statistical model finally retained, after analyzing all possible combinations of the predictive variables, includes as dependent variable: IGIA and three regression variables: Capitaliz, TD_A, TA_A.
$I G I A=+0.328 * T D \_A-0.565 * T A \_A+1.05^{*}$ Capitaliz

(0.875)

(0.548)

(0.232)

Note: $n=180$, R-squared $=0.846$ (standard errors in parentheses).

The validated model, determined according to the regression equation by the 2 SLS method, with the value of the coefficient of determination $\mathrm{R}^{2}=0.846$, demonstrates that the regression equation describes in proportion of $84.59 \%$ the variation of the dependent variable and of the whole phenomenon, which causes us to state that and the second objective of empirical research was achieved. Thus, as can be seen from the analysis, we argue that the model structured by activity sectors, is much more significant for the manufacturing companies, than for those active in the services sector, which confirms the assertion of the $\mathrm{H3}$.

Regarding the achievement of the second objective of the empirical study - proposals on extending the structure of the balance sheet that also include the value of intangible assets generated internally, we specify that the model allows future actions of the regulatory bodies depending on the potential and the influences of the evaluators entities, for the purpose of establishing a regulatory framework through which IGIA is to be included as a separate position in financial reporting.

The importance of this study relies in the fact that it can help any type of economic entity to evaluate as accurately as possible the difference between its book value and the market value, while at the same time offering significant support to other studies that have addressed this topic. Besides the fact that the results obtained can help us to evaluate the impact of the IGIA value in maximizing the market value of these companies on the international financial market, they also show us that investments in IA significantly influence the long-term competitive advantage.

\section{Conclusions}

In this paper we examined the impact of the value of internally generated intangible assets on the market value of an entity, being dissociated by the analysis of the concept of accounting value of the entity. The concept of market value of the entity is equivalent with the term of market capitalization.

We consider that, through the study carried out and the proposed econometric models, the 
lack of structured information regarding the empirical approach of the IA is supplemented by the prism of their evaluation. For example, a consumer-oriented country, such as the majority of the former socialist countries of Eastern Europe, where investment policies are deficient, and the study establishes the premises of innovative approaches in terms of systemic development through the incorporation of technologies and know-how in the existing products on the Romanian market. These premises can be generative, in the case of implementation, of sustainable growth and an added value, in the context of changing the strategic approach from consumption to investments. We believe that, by using and implicitly increasing the share of IA in the assets of the Romanian entities, a higher profitability threshold will be reached, which will allow the professional restructuring of human resources, the redirection of the use of the existing material resources and finally the systemic quality of the economic activities as a whole.

The determined model is useful to the stakeholders because it provides very precise information of the possible directions of development of the entities from the point of view of the IA, the managers who allow them to make a quick diagnosis of the needs of IA, as well as the quantification of the holdings of elements of an intangible nature, and in the same time the study is useful to other users of financial information who can obtain relevant information on the real value of the entity, giving them a forecasted picture of the possible evolution and at the same time allowing the identification of the non-apparent vulnerabilities that can affect the economic activity from the strategic perspective. The model allows to approach a standardized direction for the regulatory bodies that evaluate both at the micro level and at the macro level the economic "health" of the entities. The deficiency of the model is that it uses information on the liquidity of the traded shares. This deficiency in fact, amplifies the role of the evaluators of entities that could collaborate with the regulatory bodies to expand the market area of the model, thus allowing the standardization and creation of a regulatory framework that will allow IGIA to be reported on the balance sheet. Because of the fact that the majority of elements of intangible nature is not recognized in the balance of the company, in order to make the empirical analysis, to get all those intangible factors unregistered in the balance sheet, that influence decisively and significantly the value of the entity, we used a proxy, named by us internally generated intangible assets, which is determined by the difference of the market value of owners' capitals on the date of the balance, and the accounting value of owners' capitals, to which is added the accounting value of intangible assets registered in the balance sheet.

Consequently, we believe that the most important benefit or advantage of keeping and evaluating correctly and accurately a company's portfolio of intangible assets is the design of a transparent means of generating the added value and the sustenable development of the business itself provided these companies rely on these types of resources and their huge potential for creating a lasting value in time. It would be also interesting to observe whether the results of the present study is confirmed for a numerous and diversified sampling of companies in the view of the field of activity.

Acknowledgment: This work is supported by project POCU 125040, entitled "Development of the tertiary university education to support the economic growth - PROGRESSIO", co-financed by the European Social Fund under the Human Capital Operational Program 2014-2020.

\section{References}

Anderson, E. W., Fornell, C., \& Mazvancheryl, S. K. (2004). Customer satisfaction and shareholder value. Journal of Marketing, 68(4), 172-185. https://doi.org/10.1509/ jmkg.68.4.172.42723

Badicu, G., \& Mihaila, S. (2016). Study regarding the relevance of the accounting subjects in the economic vocational training of non-accountant specialists. The Audit Financiar Journal, Chamber of Financial Auditors of Romania, 14(140), 897-908. https://doi. org/10.20869/AUDITF/2016/140/897

Bareja, K., Gawart, M., \& Giedroyc, M. (2017). Evolution of Intangible Assets Recognised in a Statement of Financial Position. In Management Challenges in a Network Economy: Proceedings of the MakeLearn and TIIM International Conference 2017 (p. 481), Lublin, Poland.

Barney, J. B. (1991). Firm resources and sustained competitive advantage. Journal 
of Management, 17(1), 99-120. Retrieved September 6, 2019, from http://www.business. illinois.edu/josephm/BA545_Fall\%202019/ Barney\%20(1991).pdf

Barney, J. B. (2001). Resource-based theories of competitive advantage: A ten-year retrospective on the resource-based view. Journal of Management, 27(6), 643-650. https://doi.org/10.1177/014920630102700602

Barth, M. E., Kasznik, R., \& McNichols, M. F. (2001). Analyst coverage and intangible assets. Journal of Accounting Research, 39(1), 1-34. https://doi.org/10.1111/1475-679X.00001

Bontis, N. (1998). Intellectual capital: an exploratory study that develops measures and models. Management Decision, 36(2), 63-76. https://doi.org/10.1108/00251749810204142

Bunget, O. C., Blidisel, R. G., Feleaga, L., \& Popa, I. E. (2014). Empirical study of intagible assets in Romanian municipalities. E\&M Economics and Management, 17(3), 136-151. https://doi.org/10.15240/tul/001/2014-3-011

Burciu, A., \& Kicsi, R. (2015). Knowledge as a distinctive resource of competitive advantage. Ecoforum Journal, 4. Retrieved October 25, 2019, from http://ecoforumjournal.ro/index.php/ eco/article/view/214

Bužinskienè, R. (2017). Determination of the value of intangible assets in the companies of Lithuania. Economics and Culture, 14(2), 55-68. https://doi.org/10.1515/jec-2017-0018

Chalmers, K., Clinch, G., Godfrey, J. M., \& Wei, Z. (2012). Intangible assets, IFRS and analysts' earnings forecasts. Accounting \& Finance, 52(3), 691-721. https://doi. org/10.1111/j.1467-629X.2011.00424.x

Chen, W., Niebel, T., \& Saam, M. (2016). Are intangibles more productive in ICT-intensive industries? Evidence from EU countries. Telecommunications Policy, 40(5), 471-484. https://doi.org/10.1016/j.telpol.2015.09.010

Chung, K. H., \& Pruitt, S. W. (1994). A simple approximation of Tobin's q. Financial Management, 23(3), 70-74. https://doi.org/10.2307/3665623

Clausen, S., \& Hirth, S. (2016). Measuring the value of intangibles. Journal of Corporate Finance, 40, 110-127. https://doi.org/10.1016/j. jcorpfin.2016.07.012

Cosmulese, C. G., Socoliuc, M., Ciubotariu, M.-S., Mihaila, S., \& Grosu, V. (2019). An empirical analysis of stakeholders' expectations and integrated reporting quality. Economic Research - Ekonomska Istraživanja, 32(1), 3963-3986. https://doi.org/10.1080/1331677X.2019.1680303
Eccles, R. G. (1991). The Performance Measurement Manifesto. Harvard Business Review, 69(1), 131-137.

Fejes, J. (2018). The role of intangible assets in the banking value creation process (Doctoral Dissertation). Corvinus University, Budapest. Retrieved September 20, 2019, from http://phd.lib.uni-corvinus.hu/995/18/Fejes_ Jozsef_ten.pdf

Gamayuni, R. R. (2015). The effect of intangible asset, financial performance and financial policies on the firm value. International Journal of Scientific \& Technology Research, 4(1), 202-212.

Garanina, T., \& Pavlova, Y. (2011). Intangible Assets and Value Creation of a Company: Russian and UK Evidence. In Proceedings of the 3rd European Conference on Intellectual Capital (pp. 165-175). University of Nicosia, Cyprus.

Glova, J., \& Mrázková, S. (2018). Impact of intangibles on firm value: empirical evidence from european public companies. Ekonomický časopis (Journal of Economics), 66(7), 665-680.

Greco, M., Cricelli, L., \& Grimaldi, M. (2013). A strategic management framework of tangible and intangible assets. European Management Journal, 31(1), 55-66. https://doi.org/10.1016/j. emj.2012.10.005

Greene, W. H. (2000). Econometric Analysis (4th ed.). Upper Saddle River, NJ: Prentice Hall.

Grosu, V. (2013). Evaluarea capitalului intelectual, Studii şi cercetări privind impactul cercetăriişi inovării asupra progresului economic (Volume 4, Postdoctoral Dissertations, pp. 397-460). Academiei Române, Bucharest.

Gu, F., \& Wang, W. (2005). Intangible assets, information complexity, and analysts' earnings forecasts. Journal of Business Finance \& Accounting, 32(9-10), 1673-1702. https:// doi.org/10.1111/j.0306-686X.2005.00644.x

lancu, E., Burciu, A., \& Kicsi, R. (2014). Innovative Economy and Knowledge Society Vectors. Ovidius University Annals, Series Economic Sciences, 14(2), 187-193.

IAS 38 - Intangible Assets. (2004). Retrieved October 9, 2019, from https://www. iasplus.com/en/standards

IFRS 3 - Business Combination. (2008). Retrieved October 9, 2019, from https://www. iasplus.com/en/standards

International Integrated Reporting Committee. (2011). Towards Integrated Reporting - Communicating Value in the 21st Century 
(Discussion Paper). Retrieved October 25, 2019, from https://integratedreporting.org/wpcontent/uploads/2012/06/Discussion-PaperSummary1.pdf

Jemna, D. (2012). Econometrie (2nd ed.). lasi: Sedcom Libris.

Jordão, R. V. D., \& Almeida, V. R. D. (2017). Performance measurement, intellectual capital and financial sustainability. Journal of Intellectual Capital, 18(3), 643-666. https://doi. org/10.1108/JIC-11-2016-0115

Lampinen, L. (2018). The accounting and reporting of internally generated intangible assets (Bachelor thesis). Aalto University Learning Centre, Espoo. Retrieved October 2, 2019, from https://aaltodoc.aalto.fi/handle/123456789/32250

Lev, B. (2001). Intangibles: Management, Measurement and Reporting. Washington, DC: Brookings Institution Press.

Matolcsy, Z., \& Wyatt, A. (2006). Capitalized intangibles and financial analysts. Accounting \& Finance, 46(3), 457-479. https://doi. org/10.1111/j.1467-629X.2006.00177.x

McConnell, J. J., \& Servaes, H. (1990). Additional evidence on equity ownership and corporate value. Journal of Financial Economics, 27(2), 595-612. https://doi. org/10.1016/0304-405X(90)90069-C

Mihaila, S. (2014). Directions of Improvement And Organisation Of Management Accounting Based On Abc-Costing Method Applied In Moldovan Manufacturing Entities. European Journal of Accounting, Finance \& Business, 2(2), 75-101.

Nakamura, L. I. (2010). Intangible assets and national income accounting. Review of Income and Wealth, 56(s1), S135-S155. https://doi.org/10.1111/j.1475-4991.2010.00390.x

Nonaka, I., \& Takeuchi, H. (1995). The knowledge-creating company. How Japanese companies create the dynamics of innovation. Oxford: Oxford University Press.

Novák, M. (2018). The Quality of Disclosure under IAS 38 in Financial Statements of Entities Listed on PSE. European Financial and Accounting Journal, 13(2), 31-44. https://doi. org/10.18267/j.efaj.208

Ocean Tomo. (2015). Retrieved October 25, 2019, from http://www.oceantomo.com/oceantomo-300/

OECD. (2008). Intellectual assets and value creation. Retrieved June 25, 2019, from https://www.oecd.org/science/inno/40637101.pdf

OECD. (2012). Corporate Reporting of
Intangible Assets: A Progress Report. Retrieved June 25, 2019, from https://www.oecd.org/daf/ ca/Intangible\%20Assets.pdf

Osinski, M., Selig, P. M., Matos, F., \& Roman, D. J. (2017). Methods of evaluation of intangible assets and intellectual capital. Journal of Intellectual Capital, 18(3), 470-485. https://doi.org/10.1108/JIC-12-2016-0138

Pastor, D., Glova, J., Liptak, F., \& Kovac, V. (2017). Intangibles and methods for their valuation in financial terms: Literature review. Intangible Capital, 13(2), 387-410. http://dx.doi. org/10.3926/ic.752

Podhorska, I., \& Siekelova, A. (2016). The impact of internally generated goodwill on the financial performance of companiesinternational comparison. In Proceedings of the 16th International Scientific Conference on Globalization and its Socio-Economic Consequences (pp. 1736-1743). Rajecke Teplice, Slovakia.

Rao, V. R., Agarwal, M. K., \& Dahlhoff, D. (2004). How is manifest branding strategy related to the intangible value of a corporation? Journal of Marketing, 68(4), 126-141. https://doi.org/10.1509/jmkg.68.4.126.42735

Salameh, A., \& Bashir, H. (2013). Intangible assets and stock price of Jordanian companies: an empirical analysis. European Journal of Business and Social Sciences, 2(9), 153-165.

Skinner, D. J. (2008). Accounting for intangibles - a critical review of policy recommendations. Accounting and Business Research, 38(3), 191-204. https://doi.org/10.1 080/00014788.2008.9663332

Smalt, S. W., \& McComb, J. M. (2016). Accounting for internally generated intangible assets. International Journal of Accounting and Taxation, 4(1), 1-15. https://doi.org/10.15640/ ijat.v4n1a1

Smith, G., \& Parr, R. (1994). Valuation of Intelectual Property and Intangible Assets (3rd ed.). New York, NY: Wiley.

Smith, C. W., Jr., \& Watts, R. L. (1992). The investment opportunity set and corporate financing, dividend, and compensation policies. Journal of Financial Economics, 32(3), 263-292. https://doi.org/10.1016/0304405X(92)90029-W

Surroca, J., Tribó, J. A., \& Waddock, S. (2010). Corporate responsibility and financial performance: The role of intangible resources. Strategic Management Journal, 31(5), 463490. https://doi.org/10.1002/smj.820 
Swanson, Z. L. (2018). Internal Intangible Asset Effect on Firm Valuation. Retrieved June 25, 2019, from https://papers.ssrn.com/sol3/ papers.cfm?abstract_id $=3134117$

Volkov, D., \& Garanina, T. (2008). Value Creation in Russian Companies: the Role of Intangible Assets. The Electronic Journal of Knowledge Management, 6(1), 63-74.
Zhang, M. (2013). The impact of internally generated goodwill on financial performance of firms. Journal of Applied Business Research, 29(6), 1809-1814. https://doi.org/10.19030/ jabr.v29i6.8217 